\title{
PENGARUH MODEL PEMBELAJARAN PROBLEM BASED LEARNING TERHADAP KEMAMPUAN KOMUNIKASI MATEMATIS SISWA KELAS VIII SMP NEGERI 2 SALAPIAN KABUPATEN LANGKAT TAHUN PELAJARAN 2018/2019
}

\author{
Regina Sabariah Sinaga ${ }^{1}$, Santa Clara Manik ${ }^{2}$ \\ STKIP Budidaya Binjai \\ reginasabariah@gmail.com
}

\begin{abstract}
ABSTRAK
Tujuan penelitian ini adalah untuk melihat kemampuan komunikasi matematis siswa yang diajarkan dengan model Problem Based Learning (PBL) dan yang diajarkan dengan pembelajaran eskperimen serta menganalisis perbedaan kemampuan komunikasi matematis antara siswa yang diajarkan dengan model Problem Based Learning dan siswa yang diajar dengan pembelajaran konvensional. Penelitian ini dilakukan di SMP Negeri 2 Salapian Tahun Pelajaran 2018/2019. Metode yang digunakan dalam penelitian ini adalah metode quasi eksperimen. Sampel penelitian diperoleh sebanyak dua kelas dengan teknik cluster random sampling yang terdiri dari kelas eksperimen (PBL) sebanyak 38 siswa dan kelas kontrol (konvensional) sebanyak 38 siswa.. instrument penelitian yang digunakan adalah tes kemampuan komunikasi matematis siswa. Teknik analisis data dalam penelitian ini adalah dengan menggunakan uji regresi untuk menguji hipotesis yang diajukan. Dari hasil perhitungan yang telah dilakukan ternyata berdasarkan hasil uji regresi diatas diperoleh $r_{\text {hitung }}$ 0,64 dan $r_{\text {tabel }}$ 0,320. Sehingga $r_{\text {hitung }}>r_{\text {tabel }}$ maka Ho ditolak dan Ha diterima. Berdasarkan uraian diatas dapat diambil kesimpulan bahwa terdapat pengaruh model pembelajaran Problem Based Learning (PBL) terhadap kemampuan komunikasi matematis siswa maka Ho ditolak. Kesimpulan hasil penelitian ini adalah bahwa pembelajaran matematika pada pokok bahasan pytagoras dengan menggunakan model Problem Based Learning berpengaruh secara signifikan terhadap kemampuan komunikasi matematis siswa dibandingkan yang menggunakan pembelajaran konvensional.
\end{abstract}

Kata kunci : $\quad$ Model Problem Based Learning, Kemampuan komunikasi Matematis Siswa. 


\section{PENDAHULUAN}

Matematika merupakan salah satu mata pelajaran yang memiliki peranan penting dalam pengembangan kemampuan matematis siswa. Hal ini sejalan dengan pendapat Suherman, dkk matematika sekolah adalah matematika yang diajarkan di sekolah, yaitu matematika yang diajarkan di pendidikan dasar dan pendidikan menengah. Matematika sekolah terdiri atas bagian-bagian matematika yang dipilih guna menumbuh kembangkan kemampuan-kemampuan dan membentuk pribadi siswa serta berpandu pada perkembangan IPTEK. Belajar matematika bagi siswa merupakan pembentukan pola pikir dalam memahami suatu pengertian maupun dalam menalar suatu hubungan diantara pengertian-pengertian. Siswa diberikan pengalaman menggunakan matematika sebagai alat untuk memahami atau menyampaikan suatu informasi misalnya melalui simbol-simbol persamaan, grafik, diagram, dan sebagainya.

Berdasarkan beberapa pendapat di atas, dapat disimpulkan bahwa matematika sekolah merupakan bagianbagian matematika yang dipilih untuk membangun pola pikir analitis, logis, sistematis, dan membentuk pribadi siswa melalui kegiatan pemecahan masalah, kreativitas, dan berkomunikasi yang kemudian diaplikasikan dalam konteks kehidupan nyata.

Adapun tujuan pembelajaran matematika adalah agar peserta didik mempunyai kemampuan untuk memahami konsep matematika, menggunakan penalaran, memecahkan masalah, mengomunikasikan gagasan dengan simbol, tabel, diagram atau media lain untuk memperjelas keadaan atau masalah serta memiliki sikap menghargai kegunaan matematika dalam kehidupan. Untuk mencapai tujuan pembelajaran matematika, salah satu kemampuan yang harus dikuasai siswa adalah kemampuan komunikasi matematis. Namun kenyataannya dilapangan menunjukkan bahwa hasil pembelajaran metamatika di Indonesia dalam aspek komunikasi matematis masih rendah, menurut Fahrurozi menyebutkan bahwa "rendahnya kemampuan komunikasi matematis di tunjukkan dalam studi Roheiti bahwa rata-rata kemampuan komunikasi matematis siswa berada dalam kualifikasi kurang". Menurut Van de Walle menyatakan bahwa "komunikasi merupakan suatu cara untuk berhubungan dengan suatu ide-ide matematis dengan mencoba menyampaikan ide tersebut kepada orang lain".

Salah satu pembelajaran matematika yang berorientasi pada kehidupan sehari-hari adalah model pembelajaran berbasis malasah (Problem Based Learning). Menurut Depdikbud dalam Gunawan, "model pembelajaran Problem Based Learning bermaksud untuk memberikan ruang gerak berpikir yang bebas kepada siswa untuk mencari konsep dan penyelesaian masalah yang terkait dengan materi yang diajarkan oleh guru di sekolah karena pada dasarnya ilmu matematika bertujuan agar siswa memahami konsep matematika dan keterkaitannya dengan kehidupan sehari-hari, memiliki keterampilan tentang alam sekitar untuk mengembangkan pengetahuan tentang proses alam sekitar, mampu menerapkan berbagai konsep matematika untuk menjelaskan gejala alam dan mampu menggunakan teknologi sederhana untuk memecahkan masalah yang ditemukan dalam kehidupan sehari-hari. Dalam Trianto proses pembelajaran PBL terdiri dari beberapa langkah yaitu: 1) 
menemukan masalah; 2) menganalisis masalah; 3) menemukan dan melaporkan; 4) mempresentasikan solusi dan merefleksi; 5) melihat kembali, mengevaluasi dan belajar secara mandiri. Seperti yang dinyatakan oleh Trianto bahwa Problem Based Learning adalah model pembelajaran yang dirancang dan dikembangkan untuk mengembangkan kemampuan siswa dalam memecahkan masalah.

\section{METODOLOGI PENELITIAN}

Metodologi dalam penelitian ini adalah dengan metode tes diagnostic untuk mengukur kemampuan awal siswa sehingga dapat digunakan sebagai pedoman pembagian kelompok.selanjutnya akan diberikan pretes dan post test pada kedua kelompok akan tetapi pada kelas eksperimen diberikan pemahaman, berupa pembelajaran dengan model pembelajaran Problem Based Learning.

\section{Jenis Penelitian}

Penelitian ini merupakan penelitian quasi experiment karena peneliti tidak dapat mengendalikan semua variabel yang mungkin berpengaruh terhadap variabel yang diteliti. Penelitian dilakukan pada dua kelompok siswa, yaitu kelompok eksperimen yang mengikuti pembelajaran model pembelajaran Problem Based Learning dan kelompok kontrol yang mengikuti pembelajaran konvensional. Adapun desain pelaksanaan penelitian sebagai berikut:

\section{Desain Penelitian}

\begin{tabular}{|l|l|l|l|}
\hline \multirow{2}{*}{ kelas } & \multicolumn{3}{|l|}{ Perlakuan } \\
\cline { 2 - 4 } & Pretest & Pembelajaran & Posttest \\
\hline kelas & $\mathrm{O}_{1}$ & $\mathrm{X}$ & $\mathrm{O}_{2}$ \\
Eksperimen & & & \\
\hline kelas Kontrol & $\mathrm{O}_{1}$ & Konvensional & $\mathrm{O}_{2}$ \\
\hline
\end{tabular}

\section{Tekhnik Analisis Data}

Dalam hal ini, teknik analisis data yang digunakan adalah melakukan pengujian pengaruh model pembelajaran problem based Learning (PBL) dengan jalan membandingkan hasil kelompok eksperimen dan kontrol dengan menggunakan uji-t.

\section{HASIL DAN PEMBAHASAN}

Materi matematika yang diajarkan pada penelitian ini adalah materi Pytagoras. Pada proses pembelajaran kedua kelompok memperoleh perlakuan yang berbeda. Kelas eksperimen dengan pembelajaran model pembelajaran Problem Based Learning (PBL). Sedangkan kelas kontrol dengan pendekatan konvensional. Oleh karena itu perubahan yang terjadi pada sampel setelah perlakuan disebabkan oleh perlakuanperlakuan dalam proses pembelajaran tersebut. Pada akhir pembelajaran kedua kelompok diberikan posttes yang digunakan untuk mengetahui kelompok mana yang memiliki hasil belajar yang lebih baik.

Berdasarkan perhitungan diperoleh hasil belajar matematika pada materi Pytagoras dengan model pembelajaran Problem Based Learning (PBL). dan Pendekatan Pembelajaran Konvensional disajikan dalam bentuk tabel distribusi berikut.

\begin{tabular}{|c|c|c|c|}
\hline \multicolumn{4}{|c|}{$\begin{array}{c}\text { Distribusi Frekuensi Hasil Tes Posttest } \\
\text { Kelas Eksperimen }\end{array}$} \\
\hline Interval & $\begin{array}{c}\text { Nilai } \\
\text { Tengah }\end{array}$ & $\begin{array}{l}\text { Frekuensi } \\
\text { (f) }\end{array}$ & $\begin{array}{l}\text { Frekuensi } \\
\text { Relatif } \\
(\%)\end{array}$ \\
\hline $41-50$ & 45,5 & 4 & 10,53 \\
\hline $51-60$ & 55,5 & 11 & 28,95 \\
\hline $61-70$ & 65,5 & 6 & 15,79 \\
\hline $71-80$ & 75,5 & 9 & 23,68 \\
\hline $81-90$ & 85,5 & 5 & 13,16 \\
\hline $91-100$ & 95,5 & 3 & 7,89 \\
\hline \multicolumn{2}{|c|}{ Jumlah } & 38 & 100 \\
\hline
\end{tabular}
frekwensi di atas, dapat dilihat bahwa persentase siswa yang memperoleh nilai tertinggi sebesar 7,89\% (sebanyak 3 orang), yaitu yang memperoleh nilai 
pada interval $91-100$. Persentase siswa yang memperoleh nilai terendah sebesar $10,53 \%$ (sebanyak 4 orang), yaitu yang memperoleh nilai pada interval $41-50$. Sedangkan yang paling banyak yaitu persentase siswa yang memperoleh nilai pada interval 51 - 60 sebesar $28,95 \%$ (sebanyak 11 orang).

Untuk kelompok kontrol, distribusi frekuensinya dapat disajikan sebagai berikut:

\section{Distribusi Frekuensi kemampuan}

\section{Komunikasi Matematis Kelas kontrol}

\begin{tabular}{|c|c|c|c|}
\hline Interval & $\begin{array}{c}\text { Nilai } \\
\text { Tenga } \\
\mathrm{h}\end{array}$ & $\begin{array}{l}\text { Frekuensi } \\
\text { (f) }\end{array}$ & $\begin{array}{c}\text { Frekuensi } \\
\text { Relatif } \\
(\%)\end{array}$ \\
\hline $41-50$ & 45,5 & 12 & 31,58 \\
\hline $51-60$ & 55,5 & 14 & 36,84 \\
\hline $61-70$ & 65,5 & 6 & 15,79 \\
\hline $71-80$ & 75,5 & 3 & 7,89 \\
\hline $81-90$ & 85,5 & 2 & 5,26 \\
\hline $91-100$ & 95,5 & 1 & 2,63 \\
\hline & $\begin{array}{c}\text { Juml } \\
\text { ah }\end{array}$ & 38 & \\
\hline
\end{tabular}

\section{Perbandingan hasil posttest kelas eksperimen dan kelas kontrol}

\begin{tabular}{|l|c|c|}
\hline \multirow{2}{*}{ Statistik } & \multicolumn{2}{|c|}{ Kelas } \\
\cline { 2 - 3 } & Eksperimen & Kontrol \\
\hline Nilai Terendah & 44 & 42 \\
\hline Nilai Tertinggi & 100 & 98 \\
\hline Mean/ Rata-rata hitung $(\bar{X})$ & 67,9 & 58,1 \\
\hline Simpangan Baku $(S)$ & 14,8 & 12,9 \\
\hline Varians $\left(S^{2}\right)$ & 218,6 & 165,9 \\
\hline & & \\
Median $\left(M_{e}\right)$ & 67,2 & 55,5 \\
\hline Modus $\left(M_{o}\right)$ & 56,5 & 52,5 \\
\hline
\end{tabular}

Berdasarkan perbandingan data statistik hasil posttest pada materi Pytagoras nilai posttest kelas eksperimen yang mendapatkan pembelajaran dengan model pembelajaran Problem Based Learning (PBL) lebih baik dari pada hasil posttest kelas kontrol yang mendapatkan pembelajaran dengan konvensional. Hal tersebut dapat dilihat dari nilai rata-rata kelas eksperimen sebesar 67,9 dengan simpangan baku 14,8 dan varians sebesar 218,6. Sedangkan nilai rata-rata kelas kontrol 58,1, dengan simpangan baku 12,9 dan varians 165,9.

Berdasarkan table distribusi frekwensi di atas, dapat dilihat bahwa persentase siswa yang memperoleh nilai tertinggi sebesar 2,63\% (sebanyak 1 orang), yaitu yang memperoleh nilai pada interval $91-100$. Persentase siswa yang memperoleh nilai terendah sebesar $31,58 \%$ (sebanyak 12 orang), yaitu yang memperoleh nilai pada interval 41 - 50 . Sedangkan siswa yang paling banyak yaitu persentase siswa yang memperoleh nilai pada interval 51-60 sebesar 36,84\% (sebanyak 14 orang)

Berdasarkan hasil penelitian diketahui nilai rata-rata kelas eksperimen 67,9 dan kelas kontrol 58,1. Hal ini disebabkan karena pada kelas eksperimen terlalu banyak anggota dalam masing-masing kelompok, sehingga menyebabkan kurang optimalnya bersimulasi. Sehingga siswa pada kelas ini kurang mampu dalam mengkombinasikan/ menggabungkan suatu kemampuan tentang materi yang sudah di pelajari sebelumnya yang masih digunakan dalam pembelajaran materi sekarang, namun rata-rata keseluruhan kemampuan siswa kelas eksperimen tetap lebih tinggi dari pada siswa kelas kontrol. Dan dari hasil pengujian hipotesis juga diperoleh bahwa rata-rata kemampuan pemecahan masalah matematika siswa yang diajarkan dengan model pembelajaran Problem Based Learning (PBL) lebih tinggi dari pada siswa yang diajarkan dengan menggunakan metode konvensional.

Selain itu, dari hasil pengamatan selama penelitian dalam pembelajaran 
menggunakan model pembelajaran Problem Based Learning (PBL) yang diterapkan pada kelas eksperimen menjadikan siswa lebih aktif karena diberi kesempatan langsung kepada siswa untuk mengalaminya. Siswa yang secara aktif dalam pengorganisasian dan penemuan informasi (pengetahuan) ketika pembelajaran akan menghasilkan peningkatan pengetahuan dan meningkatkan keterampilan berpikir.

Hal ini membuktikan bahwa model pembelajaran Problem Based Learning (PBL) menjadi menarik karena dalam pelaksanaannya siswa dapat menunjukan kemampuannya pemecahan masalah matematika kepada siswa lain. Siswa yang mampu menjawab soal dari guru atau siswa lain akan merasa bangga dan senang, sedangkan siswa yang belum biasa mengerjakan soal akan tertantang sehingga akan termotivasi untuk lebih giat lagi dalam belajar dan pada akhirnya akan meningkatkan kemampuan siswa pada pemecahan masalah.

Sebaliknya dalam pembelajaran secara konvensional pada kelas kontrol, siswa tidak terlibat secara optimal dan cenderung pasif. Keterlibatan siswa hanya sebatas mendengarkan, dan mencatat konsep-konsep yang diberikan. Siswa tidak diberi kesempatan untuk mengalami sendiri, memahami, menemukan, dan membuktikan konsepkonsep tersebut. Dengan demikian siswa belajar dengan cara hafalan dan kadangkadang tidak memahami isi materi. Hal tersebut tidak cukup mendukung dalam penguasaan masalah matematika.

Dengan demikian ternyata terbukti bahwa penggunaan model pembelajaran Problem Based Learning (PBL) dapat meningkatkan kemampuan komunikasi matematis siswa sehingga hasil akhir siswa pada kelas eksperimen lebih tinggi dibandingkan kemampuan memecahkan masalah matematika matematika pada kelas kontrol.

Berdasarkan penelitian yang telah dilakukan, maka dapat disimpulkan bahwa penggunaan model pembelajaran Problem Based Learning berpengaruh terhadap kemampuan komunikasi matematis siswa kelas VIII pada materi pytagoras di SMP Negeri 2 Salapian Kecamatan Salapian Kabupaten Langkat tahun pelajaran 2018/2019.

Berdasarkan hasil uji regresi diatas diperoleh $r_{\text {hitung }} 0,64$ dan $r_{\text {tabel }}$ 0,320. Sehingga $r_{\text {hitung }}>r_{\text {tabel }}$ maka $\mathrm{H}_{o}$ ditolak dan $\mathrm{H}_{a}$ diterima. Berdasarkan uraian diatas dapat diambil kesimpulan bahwa terdapat pengaruh model pembelajaran Problem Based Learning (PBL) terhadap kemampuan komunikasi matematis siswa. Sesuai dengan Interpretasi Koefesien Korelasi product moment pada tingkatan hubungan kuat. 


\section{DAFTAR PUSTAKA}

Ali Gunawan. Penerapan Metode PBL Berbasis

Performanceassesment

Terhadap Motivasi Dan Hasil Belajar Matematika Kelas X Sman I Kajen Kabupaten Pekalongan T.P 2010/ 2011

Erman Suherman dkk. Strategi Pembelajaran

Matematika

Kontemporer. Bandung: FMIPA UPI.2001

Mahmudi, Ali. "Komunikasi Dalam Pembelajaran Matematika". Jurnal MIPA UNHALU, 8(1), 1-9. 2009

Marhaeni Fajar, Ilmu Komunikasi Teori

Dan Praktik,

Yogyakarta, Graha Ilmu . 2009
Permendiknas. Tujuan Pembelajaran Matematika di Sekolah. Jakarta. 2006

Rohaeti. Pembelajaran Dengan Metode Improve Untuk Meningkatkan Pemahaman dan Kemampuan

Komunikasi Matematik Siswa SLTP. Tesis Pada APPS Universitas Pendidikan Indonesia . Bandung,2003

Trianto. Mendesain Model Pembelajaran InovatifProgresif, Jakarta: Kencana. 2010

Walle, john A. Matematika Sekolah Dasar dan Menengah (Pengembangan dan Pengajaran). Edisi keenam. Jakarta: Erlangga. 2008 